\title{
EMISSIONS MONITORING OF HEAVY METALS AND THEIR COMPOUNDS RESULTED FROM COMBUSTION PROCESSES IN CLINKER KILNS IN ROMANIA
}

\author{
CRISTIAN CIOBANU ${ }^{1}$, GHEORGHE VOICU ${ }^{2 *}$, MAGDALENA - LAURA TOMA ${ }^{2}$, \\ PAULA TUDOR ${ }^{2}$
}

\author{
${ }^{I}$ CEPROCIM SA Bucharest, Preciziei Blvd., Sector 6 - 062203, Bucharest, Romania \\ ${ }^{2}$ University POLITEHNICA of Bucharest, Splaiul Independentei, no. 313, sector 6, \\ Bucharest, Romania
}

\begin{abstract}
With the dust arising from the clinker kilns and grill coolers (the major pollution sources in a cement plant), also heavy metals and their compounds (in the form of powders and vaporous), originating from fuels and raw materials, are pumped into the air. The paper presents some aspects regarding the monitoring of heavy metals contained in the combustion gases from a Romanian cement factory. The fuels used in the incinerator varied from coal/petroleum coke, refuse oils (from waste oils and their emulsions, up to sludge, paraffin, tars, contaminated soil), rubber (including whole used tires), plastic, paper, leather, textiles, wood (including sawdust), as such or impregnated/contaminated with various substances from industrial sources or sorted household wastes, sludge (previously dried) from wastewater treatment plants. In addition, the list of over 100 types of waste that can be co-processed can be found in integrated authorizations of cement plants. However, the level of heavy metals in the combustion gases was in allowed limits.
\end{abstract}

Keywords: heavy metal, mercury, cement industry, incinerator, clinker, environment

\section{INTRODUCTION}

Cement production begins in limestone quarry with excavating the limestone and clay. These are then broken into a coin size pieces. These raw materials, together with an iron enriched material, are homogenized in a powder, called ,raw meal”. The raw meal is heated to a temperature of $1450^{\circ} \mathrm{C}$. The high temperature transforms the flour into a new material, called clinker. Clinker is chilled then ground together with gypsum to a fine powder. This is Portland cement. In order to obtain different cement types, slag and/or fly ash is added (material resulted from combustion of coal or other mineral materials) [1].

In the cement obtaining process, the main pollutants are:

- dust (from point sources, diffuse sources) with a different composition and size distribution depending on the technological equipment that produce it;

- greenhouse gases ( $\mathrm{SOx}, \mathrm{NO}_{\mathrm{X}}, \mathrm{CO}_{2}, \mathrm{CO}, \mathrm{HCl}, \mathrm{HF}, \mathrm{COV}, \mathrm{NH}_{3}$ );

- heavy metals (Ba, Be, Cr, As, Ni, Al, Ti, Ca, Fe, Mn, Cu, Ag, Sb, Cd, Pb, Se, Zn, K, Na, Tl, Hg);

- dioxins and furans (PCDD and PCDF), [2 - 12].

With the dust arising from the clinker furnaces and grill coolers (the major pollution sources in a cement plant), it also results heavy metals and their compounds (in the form of powders and vaporous), originating from fuels

\footnotetext{
* Corresponding author, email: ghvoicu_2005@yahoo.com

(C) 2018 Alma Mater Publishing House
} 
and raw materials are pumped into the air, [4-7]:

- $\mathrm{Hg}, \mathrm{Cd}, \mathrm{Tl}$ (dusts and vapors);

- As, Co, Ni, Se, Te (dusts);

- $\mathrm{Sb}, \mathrm{Cr}, \mathrm{Cu}, \mathrm{Sn}, \mathrm{Mn}, \mathrm{Pb}, \mathrm{V}, \mathrm{Zn}$ (dusts).

Heavy metals are present in the raw materials and fuels in varying amounts. The behaviour of heavy metals in clinker kiln depends on their volatility. Non-volatile metals and metal compounds remain in the process and live the furnace fixed in the clinker, the semi-volatile metals are partly taken over by the gaseous phase at sintering temperature and condenses on the material from the colder areas of the furnace and the volatiles can behave just like the semi-volatile but it may also be emitted into the atmosphere with the combustion gases, [2, 6, 8].

The volatile elements of thallium $(\mathrm{Tl})$ and mercury $(\mathrm{Hg})$ cannot be adequately controlled and, therefore, the most efficient way of including them into the stipulated limits is to limit their quantity in combustible waste in order not to increase their concentration in the system, taking into account that most of the heavy metals are contained in the raw materials and do not depend on the fuels used. Heavy metals contained into the raw materials and fuels are incorporated into clinker in stable forms.

Heavy metal emissions in the form of dust suspensions are deposited on the ground at various distances from the source of emission, depending on the particle size and the intensity of the air current. The larger the particle size the more they are deposited closer to the source of emission, which makes the soil in its vicinity to be polluted with heavy metals, [2-12].

Heavy metals are known to be less mobile, which means that once they get into the ecosystem is extremely difficult to eliminate them. Due to their low mobility, heavy metals are concentrated in each trophic level, the highest concentration being reached at the chain end and hence at humans. This phenomenon is called bioaccumulation. At each trophic level, high concentrations of heavy metals can result in conditions which lead to significant mortality, causing serious disturbances in the ecosystem, $[2,6,8]$.

Heavy metals together with other elements founded in emissions from the clinker production can be classified in three categories, [2, 6, 8, 9]:

- non-volatile or poorly volatile: $\mathrm{Al}, \mathrm{As}, \mathrm{Ba}, \mathrm{Ca}, \mathrm{Cr}, \mathrm{Cu}, \mathrm{Fe}, \mathrm{Mn}, \mathrm{Ni}, \mathrm{Ag}, \mathrm{Ti}$ and $\mathrm{V}$. These are incorporated almost $100 \%$ into clinker and the emission does not occur. As a rule, the amount of heavy metal emissions from the non-volatile elements is always much less than $0.1 \%$ of the corresponding amount of elements entered into the system;

- semi-volatile: $\mathrm{Sb}, \mathrm{Cd}, \mathrm{Pb}, \mathrm{Se}, \mathrm{Na}$ and $\mathrm{Zn}$. These elements are not completely absorbed into the clinker, but can be found in a significant proportion on retained dust from the de-dusting equipment. Since dust is $100 \%$ returned to the furnace, these elements do not accumulate in internal cycles and leave the system in the form of stack emissions;

- volatile: $\mathrm{Tl}$ and $\mathrm{Hg}$. Due to volatility, these elements tend to leave the system in the form of emissions and partially accumulate in clinker. A large part of these elements, leaving the furnace with the combustion gases, is retained in the raw meal in the flour mill and is returned to the furnace by creating so-called external cycles.

In Table 1 are shown the average limit emission values $\left(\mathrm{mg} / \mathrm{Nm}^{3}\right)$ for heavy metals in the cement industry according to the 278/2013 Law (published in the first part of Official Monitor no. 671 from 11.01.2013) on industrial emissions from a sampling period of a minimum of 30 minutes and a maximum of 8 hours.

Table 1. Average emission limit values for heavy metals permitted in the cement industry, [1].

\begin{tabular}{|c|c|}
\hline Toxicity class & $\begin{array}{c}\text { Emission limit values, according to 278/2013 law, } \\
\mathrm{mg} / \mathrm{Nm}^{3}, 10 \% \mathrm{O}_{2}\end{array}$ \\
\hline $\mathrm{Cd}+\mathrm{Tl}$ & 0.05 \\
\hline $\mathrm{Hg}$ & 0.05 \\
\hline $\mathrm{Sb}+\mathrm{As}+\mathrm{Pb}+\mathrm{Cr}+\mathrm{Co}+\mathrm{Cu}+\mathrm{Mn}+\mathrm{Ni}+\mathrm{V}$ & 0.5 \\
\hline
\end{tabular}

\section{MATERIALS AND METHODS}

Measurements were made during March 2014 - October 2016, at the Holcim SA cement plant, located in Aleșd, 
Romania, at the chimney of the clinker rotary kiln (CR). In addition, the chimney, having a $90 \mathrm{~m}$ height and a 3800 $\mathrm{mm}$ diameter, is equipped with a bag filter housing. Measurements were made during two consecutive days and in two operating modes: mixed (CR with meal mill) and direct (CR without meal mill). The thermic energy required for the clinkering process is obtained by burning coal and petroleum coke as primary fuel. They are dried/grounded in the coal mill and pulverized in the burner flame. This burner enables the simultaneous use of several fuel types: coal/coke, fuel or alternative fuels (wastes) [9]. It should be noted that the bag filter housing is the solution adopted for depollution technological equipment of the cement plant.

The following standards were used to determine the emissions of heavy metals and their compounds: SR EN 13211: 2003 - for the determination of total mercury concentration in the exhaust gases from waste incinerators for a range of mercury concentrations between $0.001-0.5 \mathrm{mg} / \mathrm{m}^{3}$; SR EN 14385:2004 - for the specific elements in the exhaust gases from incinerators in concentrations between $0.005-0.5 \mathrm{mg} / \mathrm{m}^{3}$. The specific elements corresponding to this standard are $\mathrm{Sb}, \mathrm{As}, \mathrm{Cd}, \mathrm{Cr}, \mathrm{Co}, \mathrm{Cu}, \mathrm{Pb}, \mathrm{Mn}, \mathrm{Tl}, \mathrm{V}$. Concentrations were expressed in $\mathrm{mg} / \mathrm{m}^{3}$ (in normal conditions $\mathrm{T}=273.15^{\circ} \mathrm{K}$ and $\mathrm{p}=101.3 \mathrm{kPa}$ ).

\subsection{Kiln operation during emissions measurements}

During the „annual emissions measurements”, the kiln must work with the average composition of raw materials and fuel mixture as it does during the year and the clinker production. If the furnace needs to be priory adjusted to the standard unit conversion $\left(\mathrm{mg} / \mathrm{m}^{3}, 0^{\circ} \mathrm{C}, 1013 \mathrm{mbar}\right.$, dried at $10 \%$ oxygen) for annual emissions measurements then the oven must be stabilized within 24 hours after adjustment.

In the kilns with tower cyclones, the emissions of nitrogen oxide $\left(\mathrm{NO}_{\mathrm{x}}\right)$, volatile organic compounds (VOC), benzene $\left(\mathrm{C}_{6} \mathrm{H}_{6}\right)$ and heavy metals (except mercury) are highly depend on the kiln operation (direct operation or mixed), [2-7].

The emissions of sulfur dioxide $\left(\mathrm{SO}_{2}\right)$, hydrochloric acid $(\mathrm{HCl})$, ammonia $\left(\mathrm{NH}_{3}\right)$, mercury $(\mathrm{Hg})$, and dioxins/furans (PCDD/PCDF) obviously depend on the kiln operation mode. Last compounds therefore must be measured in both operation modes (direct/mixed). If this is not possible then the direct operation mode is preferred $[2-5,8-11]$.

The calibration of the installed measurement equipment is checked at least once a year. During the calibration measurements, only the accuracy of the installed monitoring equipment is verified to confirm the continuous measurements quality, namely the measured values of the continuous monitoring emissions equipment that is controlled by parallel measurements of a certified measurements laboratory using standard reference methods. For this reason, it requires a high variability of measured values.

Calibration measurements can be made with any type of meal and fuel, as long as kiln emissions are in the „,normal" range. During such calibration measurements, changes in the composition of raw material or fuel are permitted. The furnace does not have to be stable. To obtain a greater variability of the measurements, calibration measurements of the furnaces with tower cyclones are made during both modes of operation (direct and mixed).

The differences in the compounds concentrations (at chimney conditions) are the result of various oxygen levels in the exhaust gas. Due to low emissions of heavy metals and $\mathrm{C}_{6} \mathrm{H}_{6}$, these components should be measured at least in direct operating condition. However, only $\mathrm{C}_{6} \mathrm{H}_{6}$ measurements are recommended in both operation modes.

The oven must be stabilized with baseline fuel ( $100 \%$ conventional/fossil fuels, $0 \%$ alternative fuels) for a period of about $24 \mathrm{~h}$ before changing the fuel. Currently baseline does not usually require a period of stabilization. Before the end of the baseline measurements (i.e. before fuel changing) and start the burning process measurement, it is necessary a stabilization period of about 8 hours.

Selecting the kiln operation mode. Dust emissions, $\mathrm{NO}_{\mathrm{x}}$, VOC, heavy metals (excluding $\mathrm{Hg}$ ) and $\mathrm{C}_{6} \mathrm{H}_{6}$ depends directly on the kiln operation type (direct/mixed). Obviously, emissions of $\mathrm{HCl}, \mathrm{SO}_{2}, \mathrm{NH}_{3}, \mathrm{Hg}$ and $\mathrm{PCDD} / \mathrm{PCDF}$ depend on the kiln operation mode. Therefore, last components should be measured in both operation modes. If this is not possible, then direct operation is preferred.

However, it should be noted that because of the typically low emissions values of heavy metals and $\mathrm{C}_{6} \mathrm{H}_{6}$, at 
least these components are measured in direct operation, but the measurements are recommended to be done in both operation mode, especially for $\mathrm{C}_{6} \mathrm{H}_{6}$.

The method is applicable for determining the total mercury concentration in the exhaust gases from waste incinerators for mercury concentrations between $0.001-0.5 \mathrm{mg} / \mathrm{m}^{3}$ (SR EN 13211:2003) and for particular elements of the incinerators exhaust gases in the concentrations domain between $0.005-0.5 \mathrm{mg} / \mathrm{m}^{3}$. Specific elements corresponding to this standard are $\mathrm{Sb}, \mathrm{As}, \mathrm{Cd}, \mathrm{Cr}, \mathrm{Co}, \mathrm{Cu}, \mathrm{Pb}, \mathrm{Mn}, \mathrm{Tl}, \mathrm{V}$ (SR EN 14385: 2004). It should be noted that, unless otherwise specified, the concentrations are expressed in $\mathrm{mg} / \mathrm{m}^{3}$ (in normal conditions $\mathrm{T}=273.15^{\circ} \mathrm{K}$ and $\mathrm{p}=101.3 \mathrm{kPa}$ ).

\subsection{Determination of heavy metal emissions from stationary sources}

A sample from the chimney is isokinetic extracted during a period of time (30 minutes). The particles emitted are collected on a heated filter (plate quartz fibre filter). The gaseous emissions that pass through the filter are collected into an aqueous acidic solution of hydrogen peroxide (analysed for all metals, including $\mathrm{Hg}$ ), respectively an aqueous acidic solution of potassium permanganate (analysed only for $\mathrm{Hg}$ ) according to EN 13284-1/2002. According to SR EN 13284/2002, filterable material must have an efficiency of at least $99.5 \%$ for a particle diameter of $0.3 \mathrm{~mm}$. The filterable material must be suitable for use in the maximum expected temperature.

Three absorbers were placed in series for effective absorption of gaseous metals. After isokinetic sampling, solid and liquid samples stored in the bottle or container made of PP or PE were kept at temperatures below $60^{\circ} \mathrm{C}$ and transported to the laboratory in order to determine the mass concentration of the specific elements of the kiln exhaust gases ( $\mathrm{Sb}, \mathrm{As}, \mathrm{Pb}, \mathrm{Cr}, \mathrm{Co}, \mathrm{Cu}, \mathrm{Mn}, \mathrm{Ni}, \mathrm{V}, \mathrm{Cd}, \mathrm{Tl}, \mathrm{Hg}$ ) by atomic absorption spectrometry according to STAS SR EN 14385:2004 and SR EN 13211:2003. The measurement can be carried out by a condensation and absorption system, as in Figure 1, or by an absorption system.

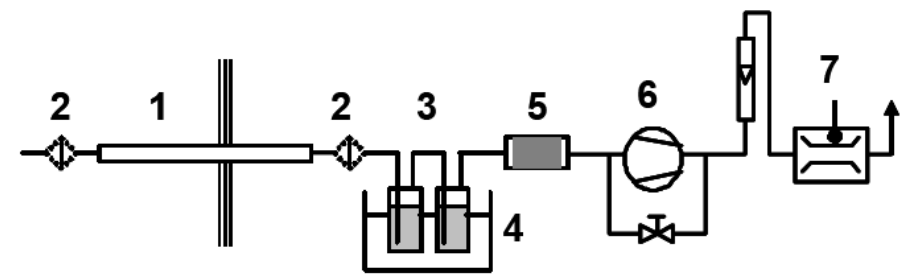

Fig. 1. The sampling method with condensation and absorption system, [12]:

1 - heated sample; 2 - heated filter (inside or outside the chimney); 3 - glass vessels for gas washing;

4 - cooling bath; 5 - absorption cartridge; 6 - pomp; 7 - apparatus for measuring the temperature and pressure of the trapped gas volume.

\section{RESULTS AND DISCUSSIONS}

The concentrations of the different heavy metal emissions are relatively low and negligible in most cases. An exception is mercury. Non-volatile elements (e.g. arsenic, vanadium, nickel) are completely embedded in the clinker. Volatile elements such as lead and cadmium usually react in chloride and sulphate excess, inside the area between kiln and granulation tower, forming slightly volatile compounds due to a large surface.

At temperatures of $700-900^{\circ} \mathrm{C}$, due to the large surface between the kiln and granulation tower, easily volatile elements (in vapour form), such as lead and cadmium, react with chlorides and sulphates in excess forming easily volatile compounds. In their turn, these compounds condense on the solid areas of the kiln, including on the material particles.

Filters are used in order to reduce dust emissions from kiln's combustion gases and from the cooling and grinding processes. $\mathrm{NO}_{\mathrm{x}}$ reduction is achieved by using a non catalytic selective reduction installation of these compounds.

In this way, easily volatile elements are accumulated in the system and precipitated again in the cyclone, almost completely enclosing itself in the clinker. 
From Table 2 and Table 3 it appears that for technological solution in which the rotary kiln with meal mill (mixed operation mode) is adopted, there is a slightly decreasing trend in heavy metals level, for $10 \% \mathrm{O}_{2}$ dry gas and $10 \% \mathrm{O}_{2}$ moist gas. The same decreasing trend of the heavy metals level is found in the Table 3 , for the rotary kiln without meal mill (direct operation mode).

In all measurements performed, in both operation mode mixed: (rotary kiln with meal mill) and direct (rotary kiln without meal mill) and in both cases $\left(10 \% \mathrm{O}_{2}\right.$ dry gas and $10 \% \mathrm{O}_{2}$ wet gas), the mercury concentration was maintained at a relatively constant level during the monitored period.

Thallium and its compounds condense in the upper part of the cyclone at temperatures between 450 and $500^{\circ} \mathrm{C}$. As a result, a new cycle may be formed between the preheating and drying of the meal and purifying the exhaust gases. Mercury and its compounds do not precipitate inside the furnace or cyclone. They condenses on the gas exhaust route due to the gas cooling and are partially absorbed by the raw material particles. This fraction is precipitated in the exhaust gas filters.

The data obtained for the heavy metals emissions, including mercury and calculated emission factors are shown in Table 2 and Table 3.

Table 2. The experimentally determined emissions of heavy metals and mercury from clinker rotary kiln.

\begin{tabular}{|c|c|c|c|c|c|c|c|}
\hline \multirow[b]{3}{*}{$\begin{array}{c}\text { Measurement } \\
\text { date }\end{array}$} & \multirow[b]{3}{*}{ Pollutant } & \multicolumn{5}{|c|}{ C.R. (rotary kiln) with raw meal mill } & \multirow{3}{*}{$\begin{array}{c}\text { Pollutant limit at } \\
10 \% \mathrm{O}_{2} \\
\text { according to } \\
278 / 2013 \mathrm{Law}, \\
\left(\mathrm{mg} / \mathrm{Nm}^{3}\right)\end{array}$} \\
\hline & & \multirow[b]{2}{*}{$\begin{array}{c}\text { Concentration, } \\
\left(\mathrm{mg} / \mathrm{Nm}^{3}\right) \\
\text { at } 10 \% \mathrm{O}_{2} *\end{array}$} & \multirow[b]{2}{*}{$\begin{array}{c}\text { Concentration, } \\
\left(\mathrm{mg} / \mathrm{Nm}^{3}\right) \\
\text { at } 10 \% \mathrm{O}_{2} * *\end{array}$} & \multicolumn{3}{|c|}{ Parameters } & \\
\hline & & & & $\begin{array}{c}\text { Gas volume } \\
\text { collected, brought } \\
\text { to standard } \\
\text { conditions }\left(\mathrm{Nm}^{3}\right) \\
\end{array}$ & $\begin{array}{c}\text { Gas volume } \\
\text { collected } \\
\text { wet, }\left(\mathrm{Nm}^{3}\right)\end{array}$ & \begin{tabular}{|c|}
$\mathrm{O}_{2}$ \\
concentration, \\
measured in \\
burnt gas, $(\%)$
\end{tabular} & \\
\hline \multirow{3}{*}{ March 2014} & $\mathrm{Cd}+\mathrm{Tl}$ & 0.0014 & 0.0011 & \multirow[b]{2}{*}{0.5178} & \multirow[b]{2}{*}{0.6502} & \multirow[b]{2}{*}{8.78} & 0.05 \\
\hline & \begin{tabular}{|c|}
$\mathrm{Sb}+\mathrm{As}+\mathrm{Pb}+$ \\
$+\mathrm{Cr}+\mathrm{Co}+\mathrm{Cu}+$ \\
$+\mathrm{Mn}+\mathrm{Ni}+\mathrm{V}$
\end{tabular} & 0.0709 & 0.0564 & & & & 0.5 \\
\hline & $\mathrm{Hg}$ & 0.0042 & 0.0033 & 0.5272 & 0.6648 & 9.07 & 0.05 \\
\hline \multirow{3}{*}{ August 2014} & $\mathrm{Cd}+\mathrm{Tl}$ & 0.0004 & 0.0002 & \multirow[b]{2}{*}{0.5379} & \multirow[b]{2}{*}{0.9735} & \multirow[b]{2}{*}{9.88} & 0.05 \\
\hline & \begin{tabular}{|c|}
$\mathrm{Sb}+\mathrm{As}+\mathrm{Pb}+$ \\
$+\mathrm{Cr}+\mathrm{Co}+\mathrm{Cu}+$ \\
$+\mathrm{Mn}+\mathrm{Ni}+\mathrm{V}$ \\
\end{tabular} & 0.0969 & 0.0535 & & & & 0.5 \\
\hline & $\mathrm{Hg}$ & 0.0105 & 0.0058 & 0.5460 & 0.9884 & 9.68 & 0.05 \\
\hline \multirow{3}{*}{ March 2015} & $\mathrm{Cd}+\mathrm{Tl}$ & 0.0034 & 0.0025 & \multirow[b]{2}{*}{0.2446} & \multirow[b]{2}{*}{0.3331} & \multirow[b]{2}{*}{10.00} & 0.05 \\
\hline & \begin{tabular}{|c|}
$\mathrm{Sb}+\mathrm{As}+\mathrm{Pb}+$ \\
$+\mathrm{Cr}+\mathrm{Co}+\mathrm{Cu}+$ \\
$+\mathrm{Mn}+\mathrm{Ni}+\mathrm{V}$ \\
\end{tabular} & 0.2453 & 0.1801 & & & & 0.5 \\
\hline & $\mathrm{Hg}$ & 0.0002 & 0.0001 & 0.2459 & 0.3305 & 10.48 & 0.05 \\
\hline \multirow{3}{*}{ July 2015} & $\mathrm{Cd}+\mathrm{Tl}$ & 0.0026 & 0.0015 & \multirow[b]{2}{*}{0.3901} & \multirow[b]{2}{*}{0.7059} & \multirow[b]{2}{*}{10.09} & 0.05 \\
\hline & \begin{tabular}{|c|}
$\mathrm{Sb}+\mathrm{As}+\mathrm{Pb}+$ \\
$+\mathrm{Cr}+\mathrm{Co}+\mathrm{Cu}+$ \\
$+\mathrm{Mn}+\mathrm{Ni}+\mathrm{V}$ \\
\end{tabular} & 0.1179 & 0.0652 & & & & 0.5 \\
\hline & $\mathrm{Hg}$ & 0.0061 & 0.0034 & 0.4049 & 0.7324 & 9.49 & 0.05 \\
\hline \multirow{3}{*}{ May 2016} & $\mathrm{Cd}+\mathrm{Tl}$ & 0.0022 & 0.0017 & \multirow[b]{2}{*}{0.2753} & \multirow[b]{2}{*}{0.3579} & \multirow[b]{2}{*}{9.87} & 0.05 \\
\hline & $\begin{array}{c}\mathrm{Sb}+\mathrm{As}+\mathrm{Pb}+ \\
+\mathrm{Cr}+\mathrm{Co}+\mathrm{Cu}+ \\
+\mathrm{Mn}+\mathrm{Ni}+\mathrm{V} \\
\end{array}$ & 0.1228 & 0.0944 & & & & 0.5 \\
\hline & $\mathrm{Hg}$ & 0.0039 & 0.0030 & 0.2912 & 0.3786 & 9.31 & 0.05 \\
\hline \multirow{3}{*}{ October 2016} & $\mathrm{Cd}+\mathrm{Tl}$ & 0.0049 & 0.0028 & \multirow[b]{2}{*}{0.1141} & \multirow[b]{2}{*}{0.2043} & \multirow[b]{2}{*}{10.12} & 0.05 \\
\hline & $\begin{array}{c}\mathrm{Sb}+\mathrm{As}+\mathrm{Pb}+ \\
+\mathrm{Cr}+\mathrm{Co}+\mathrm{Cu}+ \\
+\mathrm{Mn}+\mathrm{Ni}+\mathrm{V} \\
\end{array}$ & 0.1283 & 0.0717 & & & & 0.5 \\
\hline & $\mathrm{Hg}$ & 0.0031 & 0.0017 & 0.1700 & 0.3048 & 9.49 & 0.05 \\
\hline
\end{tabular}

$\mathrm{NB}: * T=273.15 \mathrm{~K}, \mathrm{p}=101.3 \mathrm{kPa}, 10 \% \mathrm{O}_{2}$, dry gas; $* * 10 \% \mathrm{O}_{2}$, wet gas 


\section{CONCLUSIONS}

The data obtained from measurements made at different clinker production plants at the national level, using different methods for the clinker preparation and types of fossil or alternative fuels - combustible wastes, are leading to the same conclusion: the heavy metals emissions during cement manufacturing processes are insignificant and have a minor impact on the environment (air, water, soil) complying with the limits imposed by of national laws and regulations.

Table 3. The heavy metals and mercury emissions of clinker rotary kiln, without raw meal mill.

\begin{tabular}{|c|c|c|c|c|c|c|c|}
\hline \multirow[b]{3}{*}{$\begin{array}{c}\text { Measurement } \\
\text { date }\end{array}$} & \multirow[b]{3}{*}{ Pollutant } & \multicolumn{5}{|c|}{ C.R. (rotary kiln) without raw meal mill } & \multirow{3}{*}{$\begin{array}{c}\text { Pollutant limit } \\
\text { at } 10 \% \mathrm{O}_{2} \\
\text { according to } \\
278 / 2013 \\
\mathrm{Law}, \\
\left(\mathrm{mg} / \mathrm{Nm}^{3}\right) \\
\end{array}$} \\
\hline & & \multirow[b]{2}{*}{$\begin{array}{c}\text { Concentration, } \\
\left(\mathrm{mg} / \mathrm{Nm}^{3}\right) \\
\text { at } 10 \% \mathrm{O}_{2} *\end{array}$} & \multirow[b]{2}{*}{$\mid \begin{array}{c}\text { Concentration, } \\
\left(\mathrm{mg} / \mathrm{Nm}^{3}\right) \\
\text { at } 10 \% \mathrm{O}_{2} * *\end{array}$} & \multicolumn{3}{|c|}{ Parameters } & \\
\hline & & & & $\begin{array}{c}\text { Gas volume } \\
\text { collected, brought } \\
\text { to standard } \\
\text { Conditions, }\left(\mathrm{Nm}^{3}\right)\end{array}$ & $\begin{array}{c}\text { Gas volume } \\
\text { collected } \\
\text { wet, }\left(\mathrm{Nm}^{3}\right)\end{array}$ & $\begin{array}{c}\mathrm{O}_{2} \\
\text { concentration, } \\
\text { measured in } \\
\text { burnt gas, }(\%)\end{array}$ & \\
\hline \multirow{3}{*}{ March 2014} & $\mathrm{Cd}+\mathrm{Tl}$ & 0.0011 & 0.0005 & \multirow[b]{2}{*}{0.4312} & \multirow[b]{2}{*}{0.8648} & \multirow[b]{2}{*}{7.49} & 0.05 \\
\hline & $\begin{array}{c}\mathrm{Sb}+\mathrm{As}+\mathrm{Pb}+ \\
+\mathrm{Cr}+\mathrm{Co}+\mathrm{Cu}+ \\
+\mathrm{Mn}+\mathrm{Ni}+\mathrm{V} \\
\end{array}$ & 0.0536 & 0.0267 & & & & 0.5 \\
\hline & $\mathrm{Hg}$ & 0.0003 & 0.0001 & 0.4364 & 0.8776 & 7.28 & 0.05 \\
\hline \multirow{3}{*}{ August 2014} & $\mathrm{Cd}+\mathrm{Tl}$ & 0.0008 & 0.0004 & \multirow[b]{2}{*}{0.1075} & \multirow[b]{2}{*}{0.2388} & \multirow[b]{2}{*}{9.20} & 0.05 \\
\hline & $\begin{array}{c}\mathrm{Sb}+\mathrm{As}+\mathrm{Pb}+ \\
+\mathrm{Cr}+\mathrm{Co}+\mathrm{Cu}+ \\
+\mathrm{Mn}+\mathrm{Ni}+\mathrm{V}\end{array}$ & 0.3683 & 0.1658 & & & & 0.5 \\
\hline & $\mathrm{Hg}$ & 0.0051 & 0.0023 & 0.2061 & 0.4580 & 8.98 & 0.05 \\
\hline \multirow{3}{*}{ March 2015} & $\mathrm{Cd}+\mathrm{Tl}$ & 0.0027 & 0.0019 & \multirow[b]{2}{*}{0.3869} & \multirow[b]{2}{*}{0.5427} & \multirow[b]{2}{*}{10.62} & 0.05 \\
\hline & $\begin{array}{c}\mathrm{Sb}+\mathrm{As}+\mathrm{Pb}+ \\
+\mathrm{Cr}+\mathrm{Co}+\mathrm{Cu}+ \\
+\mathrm{Mn}+\mathrm{Ni}+\mathrm{V} \\
\end{array}$ & 0.1453 & 0.1036 & & & & 0.5 \\
\hline & $\mathrm{Hg}$ & 0.0009 & 0.0006 & 0.1240 & 0.1730 & 10.65 & 0.05 \\
\hline \multirow{3}{*}{ July 2015} & $\mathrm{Cd}+\mathrm{Tl}$ & 0.0035 & 0.0016 & \multirow[b]{2}{*}{0.3544} & \multirow[b]{2}{*}{0.7774} & \multirow[b]{2}{*}{9.08} & 0.05 \\
\hline & $\begin{array}{c}\mathrm{Sb}+\mathrm{As}+\mathrm{Pb}+\mathrm{Cr} \\
+ \\
+\mathrm{Co}+\mathrm{Cu}+\mathrm{Mn}+ \\
+\mathrm{Ni}+\mathrm{V} \\
\end{array}$ & 0.0508 & 0.0232 & & & & 0.5 \\
\hline & $\mathrm{Hg}$ & 0.0075 & 0.0034 & 0.3719 & 0.8169 & 9.26 & 0.05 \\
\hline \multirow{3}{*}{ May 2016} & $\mathrm{Cd}+\mathrm{Tl}$ & 0.0014 & 0.0008 & \multirow[b]{2}{*}{0.2834} & \multirow[b]{2}{*}{0.3911} & \multirow[b]{2}{*}{8.54} & 0.05 \\
\hline & $\begin{array}{c}\mathrm{Sb}+\mathrm{As}+\mathrm{Pb}+ \\
+\mathrm{Cr}+\mathrm{Co}+\mathrm{Cu}+ \\
+\mathrm{Mn}+\mathrm{Ni}+\mathrm{V} \\
\end{array}$ & 0.0264 & 0.0147 & & & & 0.5 \\
\hline & $\mathrm{Hg}$ & 0.0019 & 0.0011 & 0.2918 & 0.5252 & 8.62 & 0.05 \\
\hline \multirow{3}{*}{ October 2016} & $\mathrm{Cd}+\mathrm{Tl}$ & 0.0027 & 0.0013 & \multirow[b]{2}{*}{0.2276} & \multirow[b]{2}{*}{0.4736} & \multirow[b]{2}{*}{10.79} & 0.05 \\
\hline & $\begin{array}{c}\mathrm{Sb}+\mathrm{As}+\mathrm{Pb}+ \\
+\mathrm{Cr}+\mathrm{Co}+\mathrm{Cu}+ \\
+\mathrm{Mn}+\mathrm{Ni}+\mathrm{V} \\
\end{array}$ & 0.0498 & 0.0241 & & & & 0.5 \\
\hline & $\mathrm{Hg}$ & 0.0008 & 0.0004 & 0.2276 & 0.4728 & 11.95 & 0.05 \\
\hline
\end{tabular}

$N B: * T=273.15^{\circ} \mathrm{K}, \mathrm{p}=101.3 \mathrm{kPa}, 10 \% \mathrm{O}_{2}$, dry gas; $* * 10 \% \mathrm{O}_{2}$, wet gas

\section{REFERENCES}

[1] * * * - Legea nr. 278/2013 privind emisiile industriale, M.O. nr. 671/2013, http://legestart.ro/legislatie-legea-nr-2782013-privind-emisiile-industriale.

[2] Cipurkovic, A., Trumic, I., Hodzic, Z., Selimbasic, V., Djozic, A., Distribution of heavy metals in Portland cement production process, Advances in applied science research, no. 5(6), 2014, p. 252-259.

[3] Heikkila, A., Modern mercury monitoring, International cement review, no. 3, 2014.

[4] Ilalokhoin, P.O., Otaru, A.J., Odigure, J.O., Abdulkareem, A. S., Okafor, J.O., Environmental impact 
assessment of a proposed cement plant in southwestern Nigeria. IOSR journal of environmental science, Toxicology and food technology, vol. 3, 2013, p. 83-99.

[5] Isikli, B., Demir, T.A., Akar, T., Berber, A., Urer, S.M., Kalyoncu, C., Canbek, M., Cadmium exposure from the cement dust emissions: A field study in a rural residence, Chemosphere, no. 63, 2006, p. 1546-1552.

[6] Kakareka, S., Kukharchyk, T., Towards improvement of heavy metals emission assessment methodology from cement production in EMEP/EEA AEI Guidebook, Proceedings 12th Joint TFEIP/EIONET meeting, 2011, Stockholm, Sweden.

[7] Mishra, S., Siddiqui, N.A., A Review on environmental and health impacts of cement manufacturing emissions, International journal of geology, agriculture and environmental sciences, vol. 2, no. 3, 2014, p. 26-31. [8] Ogunkunle, C.O., Fatoba, P.O., Contamination and spatial distribution of heavy metals in topsoil surrounding a mega cement factory, Atmospheric pollution research, no. 5(2), 2014, p. 270-282.

[9] Regional Agency for Environmental Protection of Cluj-Napoca, Region 6 Northwest integrated environmental authorization no. 92 - NV 6 of 30.10.2007 revised on 21.12.2009, Holcim (Romania) SA Cement Alesd.

[10] Tolleback, C., Easy mercury monitoring, International cement review, no. 8, 2013.

[11] Vizcaino, C., Glesmann, S., Dynamic mercury control, International cement review. ADA carbon solution LLC, USA, no. 2, 2016.

[12] Waltisberg, J., Lang, Th., Emission monitoring and reporting (EMR). Guidelines for continuous emissions measurements in Holcim cement plants, HGRS-CTS/MT, HGRS-CIE/ETPS, 2003-02/E. 